\title{
The role of low-fat diets in body weight control: a meta-analysis of ad libitum dietary intervention studies
}

Citation for published version (APA):

Astrup, A. V., Grunwald, G. K., Melanson, E. L., Saris, W. H. M., \& Hill, J. O. (2000). The role of low-fat diets in body weight control: a meta-analysis of ad libitum dietary intervention studies. International Journal of Obesity, 24(12), 1545-1552. https://doi.org/10.1038/sj.ijo.0801453

Document status and date:

Published: 01/01/2000

DOI:

10.1038/sj.ijo.0801453

Document Version:

Publisher's PDF, also known as Version of record

\section{Please check the document version of this publication:}

- A submitted manuscript is the version of the article upon submission and before peer-review. There can be important differences between the submitted version and the official published version of record.

People interested in the research are advised to contact the author for the final version of the publication, or visit the DOI to the publisher's website.

- The final author version and the galley proof are versions of the publication after peer review.

- The final published version features the final layout of the paper including the volume, issue and page numbers.

Link to publication

\footnotetext{
General rights rights.

- You may freely distribute the URL identifying the publication in the public portal. please follow below link for the End User Agreement:

www.umlib.nl/taverne-license

Take down policy

If you believe that this document breaches copyright please contact us at:

repository@maastrichtuniversity.nl

providing details and we will investigate your claim.
}

Copyright and moral rights for the publications made accessible in the public portal are retained by the authors and/or other copyright owners and it is a condition of accessing publications that users recognise and abide by the legal requirements associated with these

- Users may download and print one copy of any publication from the public portal for the purpose of private study or research.

- You may not further distribute the material or use it for any profit-making activity or commercial gain

If the publication is distributed under the terms of Article $25 \mathrm{fa}$ of the Dutch Copyright Act, indicated by the "Taverne" license above, 


\title{
The role of low-fat diets in body weight control: a meta-analysis of ad libitum dietary intervention studies ${ }^{\dagger}$
}

\author{
A Astrup ${ }^{1 *}$, GK Grunwald², EL Melanson², WHM Saris ${ }^{3}$ and JO Hill ${ }^{2}$ \\ ${ }^{1}$ The Research Department of Human Nutrition and LMC, The Royal Veterinary and Agricultural University, Frederiksberg, Denmark; \\ ${ }^{2}$ Center for Human Nutrition. University of Colorado Health Sciences Center, Denver, CO, USA; and ${ }^{3}$ University of Maastricht, \\ Maastricht, The Netherlands
}

OBJECTIVES: Low-fat high-carbohydrate diets are recommended to prevent weight gain in normal weight subjects and reduce body weight in overweight and obese. However, their efficacy is controversial. We evaluated the efficacy of ad libitum low-fat diets in reducing body weight in non-diabetic individuals from the results of intervention trials. DESIGN: Studies were identified from a computerized search of the Medline database from January 1966 to July 1999 and other sources. Inclusion criteria were: controlled trials lasting more than 2 months comparing ad libitum low-fat diets as the sole intervention with a control group consuming habitual diet or a medium-fat diet ad libitum.

MAIN OUTCOME MEASURES: Differences in changes in dietary fat intake, energy intake and body weight. Weighted mean differences for continuous data and $95 \%$ confidence intervals (Cls) were calculated.

RESULTS: Two authors independently selected the studies meeting the inclusion criteria and extracted data from 16 trials (duration of 2-12 months) with 19 intervention groups, enrolling 1910 individuals. Fourteen were randomized. Weight loss was not the primary aim in 11 studies. Before the interventions the mean proportions of dietary energy from fat in the studies were $37.7 \%(95 \% \mathrm{Cl}, 36.9-38.5)$ in the low-fat groups, and $37.4 \%(36.4-38.4)$ in the control groups. The low-fat intervention produced a mean fat reduction of $10.2 \%(8.1-12.3)$. Low-fat intervention groups showed a greater weight loss than control groups $(3.2 \mathrm{~kg}, 95 \%$ confidence interval $1.9-4.5 \mathrm{~kg} ; \boldsymbol{P}<0.0001)$, and a greater reduction in energy intake $(1138 \mathrm{~kJ} /$ day, $95 \%$ confidence interval $564-1712 \mathrm{~kJ} /$ day, $P=0.002)$. Having a body weight $10 \mathrm{~kg}$ higher than the average pre-treatment body weight was associated with a $2.6 \pm 0.8 \mathrm{~kg}(P=0.011)$ greater difference in weight loss.

CONCLUSION: A reduction in dietary fat without intentional restriction of energy intake causes weight loss, which is more substantial in heavier subjects.

International Journal of Obesity (2000) 24, 1545-1552

Keywords: low-fat diets; weight loss; obesity; humans; body weight regulation

\section{Introduction}

Dietary guidelines recommend a reduction in total dietary fat content to less than $30 \%$ of the energy intake to help reduce the prevalence of obesity, ischaemic heart disease and certain cancers. However, the robustness of the data providing the scientific evidence for a causal link between dietary fat and obesity has been challenged. Katan et al have questioned the importance of low fat diets in the prevention and treatment of obesity, ${ }^{1}$ and Willett has stated that 'Diets high in fat do not appear to be the primary cause of the prevalence of excess body fat in our society, and reductions in [dietary] fat will not be the solution' and 'in the longer term, fat consumption

\footnotetext{
*Correspondence: A Astrup, FHE, Rolighedsvej 30, 1958 Frederiksberg C, Denmark.

E-mail: ast@kvl.dk

Received 26 June 2000; revised 19 July 2000; accepted 19 July 2000

†A preliminary version of this meta-analysis was presented at the meeting 'Obesity and the Metabolic Syndrome, in Ystad, Sweden, 1999.42
}

within the range of $18-40 \%$ appears to have little if any effect on body fatness'. ${ }^{2}$ These views have been disseminated to the public, and many now advocate that saturated fat be replaced by monounsaturated fat rather than by carbohydrate. If this advice is followed the current fat consumption, which already exceeds the recommended level, will be maintained or even further increased. Thus knowing whether dietary fat facilitates body weight gain and obesity, and whether reducing dietary fat can aid weight loss is crucial to formulating nutritional advice and policies.

Evidence based on observational studies looking for associations between habitual dietary fat intake and body fatness can be confounded by lack of control for factors such as physical activity, smoking etc, but can also have other limitations due to the reliance on information on dietary intakes given by the subjects under examination. Accurate information on dietary fat intake is difficult to achieve in populations that have been recommended to reduce fat intake, because they may eat a diet closer to the recommendations during the dietary survey or specifically underreport fat intake. ${ }^{3}$ It is well established that overweight and 
obese subjects underreport their energy intake by $30-$ $40 \%,{ }^{4}$ and fat may be over-represented in this underreporting. ${ }^{5}$ Studies in health conscious populations (eg United States) show that high-fat foods are underreported, whereas low fat foods are overreported, ${ }^{6}$ and it seems to be easier to demonstrate positive associations between dietary fat intake and subsequent weight changes in less health conscious populations (eg China ${ }^{7}$ ).

A large body of short-term studies on appetite and energy intake shows that fat is less satiating than carbohydrate and protein when compared Joule for Joule, and that high-fat foods are more likely than low-fat foods to induce passive overconsumption and weight gain. ${ }^{8-11}$ Longer term low-fat intervention studies show large variability and the inconsistent outcomes have produced the aforementioned scepticism about the effectiveness of low-fat diets. We therefore found it pertinent to look more systematically at the evidence from ad libitum intervention studies to examine the effect of reducing dietary fat on body fatness. Hence, the aim of this review was to conduct a meta-analysis of controlled intervention studies of low fat ad libitum diets in order to assess the effects on body weight, and furthermore to elucidate factors previously reported to influence weight loss such as pre-treatment body weight and degree of dietary fat reduction. ${ }^{12}$

\section{Methods}

\section{Literature search}

The initial search of the literature from January 1966 to July 1999 was conducted using Medline (US National Library of Medicine), for studies having the keywords 'body weight', 'weight loss', 'weight reduction', 'body weight changes', 'fat restricted', 'ad libitum low fat diet', 'low-fat diet', 'low-cholesterol diet' or 'reduced fat'. In addition to this search, extensive cross referencing searches were also performed and published abstracts were also evaluated for inclusion. This procedure was carried out by two independent investigators.

\section{Inclusion criteria}

The initial search revealed 218 publications. Studies were then excluded if the duration of the intervention period was less than 2 months $(n=47)$, if the low-fat diet was isocaloric (ie energy intake was adjusted to maintain body weight, $n=9$ ), if total energy intake was restricted $(n=48)$, if there were other interventions which could affect weight loss $(n=12)$, if the study involved patients with non-insulin dependent diabetes mellitus $(n=6)$, if drugs were given which may have affected weight loss $(n=5)$, if no proper control group existed $(n=19)$ or if no numerical values for the pre-treatment and final body weights and/or the pre-treatment and final dietary fat intake were provided $(n=41)$. Where results from the same study are reported in more than one publication, the data are only included once $(n=15)$. A total of 16 publications reporting 19 intervention groups met the inclusion criteria. Study characteristics are shown in Table 1. These studies included a total of 1910 individuals, $62 \%$ women and $38 \%$ men.

\section{Study description}

Three studies were carried out in women with an increased risk of breast cancer or breast dysplasia; ${ }^{13-15}$ eight studies reported in seven publications assessed diets in prevention or treatment of cardiovascular disease, ${ }^{16-22}$ three studies examined weight loss diets, ${ }^{23-25}$ and five studies reported in three publications examined effects of diet on both blood lipids and body weight. ${ }^{26-28}$ Fourteen studies were randomized controlled trials, 13 using a parallel design and one a cross-over design. The control groups were either advised to maintain their regular diet or to consume a diet with a fat content as in the background population. Data was only included from intervention periods, rather than longer-term follow-up data. We would have preferred to use body mass index (BMI, weight $/$ height ${ }^{2}$ ) to get a better proxy for body fatness than provided by body weight, but BMI was not reported in all the studies and its estimation would have increased the error in variation. Mean body mass index of the studies ranged from 21 to $30 \mathrm{~kg} / \mathrm{m}^{2}$. Data abstraction was performed by two separate investigators, and the results cross checked so as to minimize potential investigator bias in data abstraction.

\section{Statistical analyses}

The standard deviation of the difference in weight change between the intervention and control groups was estimated by standard equations from the reported standard error, standard deviations or $95 \%$ confidence intervals (CIs) of the changes within the groups and differences between the groups. Standard methods of meta-analysis ${ }^{29}$ were used to carry out a chi-square test of homogeneity of study means, a fixed effects estimate, standard error and test of the difference in weight change between intervention and control diets, and a random effects estimate, standard error and test of the same difference in weight change. A linear regression analysis was conducted to test for relationships between differences in changes in body weight in intervention and control groups and the following independent variables: average pre-treatment body weight, average age, gender indicator (percent of male subjects $>50 \%, y / n$ ), duration of trial and difference between intervention and control groups in change in percentage of energy intake from fat. A quadratic effect of duration was considered to allow for the possibility that weight loss was not constant 


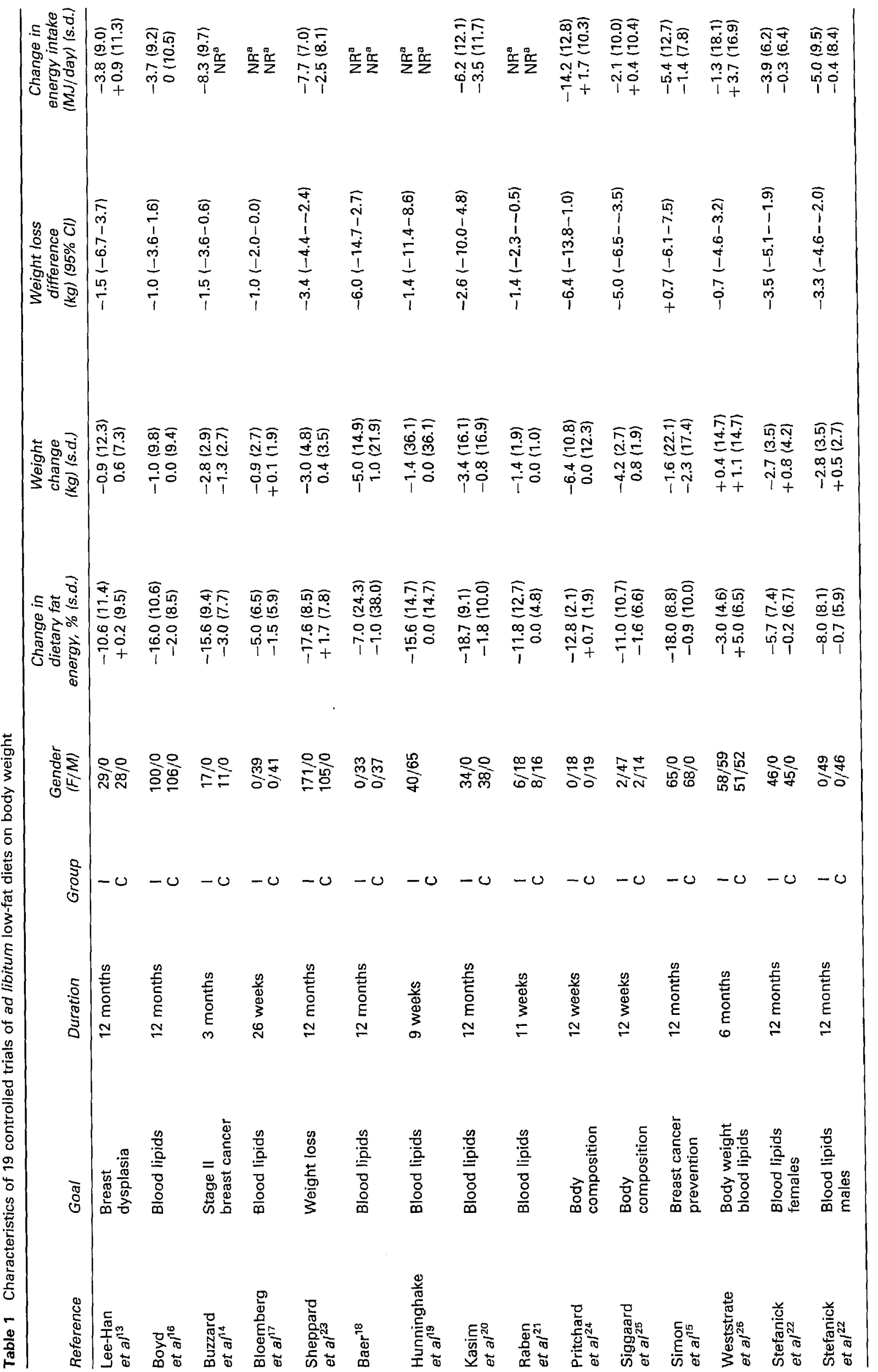


over time, and the gender indicator was included in evaluating the effect of pre-treatment body weight to adjust for the effect of gender in interpreting pretreatment weight.

- The study by Hunninghake ${ }^{19}$ used a crossover design but was treated in the analysis as if it was a parallel design. This gives an overestimate of the standard deviation, resulting in a lower meta-analysis and regression weight for that study. Because data were reported separately, the study by Stefanick et $a l^{22}$ was treated as two separate studies, one for men and one for women. In the studies by Skov et $a l^{27}$ and by Saris et $a^{28}$ there were two different low-fat intervention treatment groups, but both used the same control group. These studies were included as two separate studies, although the control group appears twice. Analyses were repeated omitting various combinations of these studies and no substantive changes in results were noted.

Statistical analyses were done using SAS (SAS Institute Inc., SAS/STAT Software: Changes and Enhancements through Release 6.12, Cary NC: SAS, 1997), with PROC MIXED in SAS used for the random effects analysis. Graphs were made using $S$ plus (S-plus User's Guide, Data Analysis Products Division, MathSoft, Seattle, WA, USA).

\section{Results}

Before the interventions the mean proportions of dietary energy from fat in the studies were $37.7 \%$ $(95 \% \mathrm{CI}, 36.9-38.5)$ in the low-fat groups, and $37.4 \%$ (36.4-38.4) in the control groups. The low-fat intervention produced a mean fat reduction of $10.8 \%$ of energy (range: $3.5-19.3 \%$ ), while no change occurred in the control groups. In the 12 (of 19) studies with reported energy intake data the intervention arms produced a mean change in total energy intake greater than that of the control group ranging from -3800 to $+100 \mathrm{~kJ} /$ day and the meta-analysis showed that the low-fat interventions as compared with the control groups produced an estimated reduction in energy intake of $959 \mathrm{~kJ} /$ day more $(95 \%$ CI, $729-$ $1189 \mathrm{~kJ} /$ day; $P<0.0001)$ in the fixed effects analysis and $1138 \mathrm{~kJ} /$ day more $(564-1712 \mathrm{~kJ} /$ day; $P=0.002)$ in the random effects analysis (Figure 1). The chisquare test of homogeneity of study means gave $Q=21.0 \quad$ (d.f. $=11, \quad P=0.033$ ), which indicated greater differences among study means than could be explained by random sampling, and in this case the random effects analysis is to be preferred. However, it is recommended that both the fixed effects and random effects analyses be carried out as a sensitivity check, and in this case the results are quite similar.

In the 19 studies included in this meta-analysis the low-fat interventions produced a weighted mean reduction in percentage of energy from fat of $10.2 \%$ (95\% CI, 8.1-12.3) as compared to the control 
groups. The corresponding difference in mean weight losses ranged from -0.7 to $11.1 \mathrm{~kg}$. The meta-analysis revealed that the low-fat interventions as compared with the control groups produced an estimated mean weight loss of $2.6 \mathrm{~kg}$ more $(95 \% \mathrm{CI}$, $2.3-3.0 \mathrm{~kg} ; P<0.0001)$ in the fixed effects analysis and $3.2 \mathrm{~kg}$ more $(1.9-4.5 \mathrm{~kg} ; P<0.0001)$ in the random effects analysis. The test of homogeneity of study means gave $Q=93.4$ (d.f. $=18, P<0.0001$ ), again indicating heterogeneity of study means and a preference for the random effects analysis. Figure 2 shows these weight losses and combined estimates along with $95 \%$ CIs. In unweighted univariate regression analyses the weight loss difference was associated only with pre-treatment average body weight adjusted for gender $(P=0.008)$, but not significantly with reduction in percentage dietary fat intake $(P=0.08)$, energy intake, gender or duration of trial. In weighted univariate regressions, none of the independent variables were significantly associated with weight loss. In unweighted multivariate regression both pre-treatment body weight $(P=0.011)$ and gender $(P=0.041)$ were significantly associated with weight loss, but these determinants were not significant in a weighted multivariate regression analysis $(P=0.15, P=0.22)$. Excluding the high-protein arm of the Skov et al study ${ }^{27}$ and the high-simple sugar arm of the Saris et $a l^{28}$ study did not essentially change the results. The significant effect of pre-treatment body weight (adjusted for gender) in the unweighted regressions can be quantified using the coefficients from the regressions. Mean difference in weight loss $(\mathrm{I}-\mathrm{C})$ was greater in studies with higher mean pre-treatment body weight. A $10 \mathrm{~kg}$ higher pretreatment mean body weight was associated with a greater difference in weight loss (I-C) of about $2.0 \pm 0.7 \mathrm{~kg}(P=0.008)$ from the univariate regression and about $2.6 \pm 0.8 \mathrm{~kg}(P=0.011)$ from the multivariate regression.

\section{Discussion}

The meta-analysis of the results from the 19 controlled ad libitum low-fat 2-12 months trials on weight change involving 1910 individuals of both genders shows that a reduction in the dietary energy from fat is associated with a spontaneous weight loss of $3.2 \mathrm{~kg}$ more $(1.9-4.5 \mathrm{~kg} ; P<0.0001)$ in the intervention than in the control group. The weight loss was not related to the duration of the low-fat intervention, probably because weight loss plateaued after 3-6 months. For this reason the results cannot be compared with the estimate by Bray and Popkin, ${ }^{1}$ who also included trials of shorter duration and without control groups in their review. Based on 28 trials they found that a reduction of $10 \%$ in the proportion of energy from fat was associated with a reduction in weight of $16 \mathrm{~g} /$ day, ${ }^{11}$ which corresponds to $2.88 \mathrm{~kg}$ over 6 months, which is within the confidence intervals of the estimate of our meta-analysis (the mean difference in percentage dietary fat reduction was $10.8 \%$ for our studies). Another meta-analysis tested the effect of the National Cholesterol Education

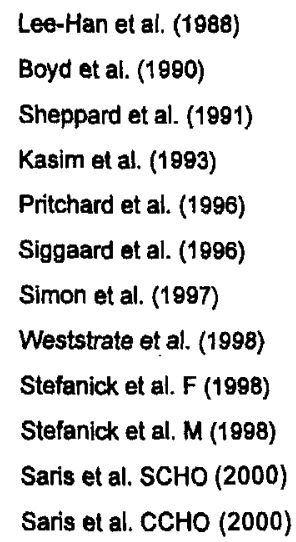

Weighted overall (fixed effects)

Weighted overall (random effects)

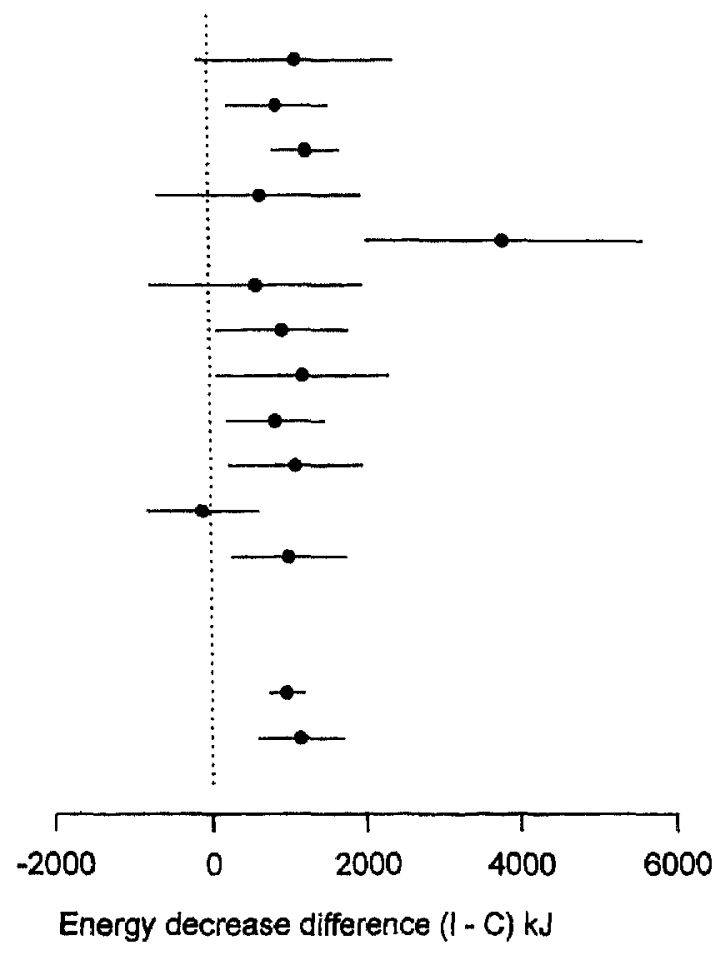

Figure 1 Differences in energy intake (change in intervention minus change in control, $\mathrm{kJ} /$ day) with $95 \%$ confidence intervals for 12 studies included in the meta-analysis. The weighted estimates and $95 \%$ confidence intervals from the fixed effects and random effects meta-analysis are also shown. 


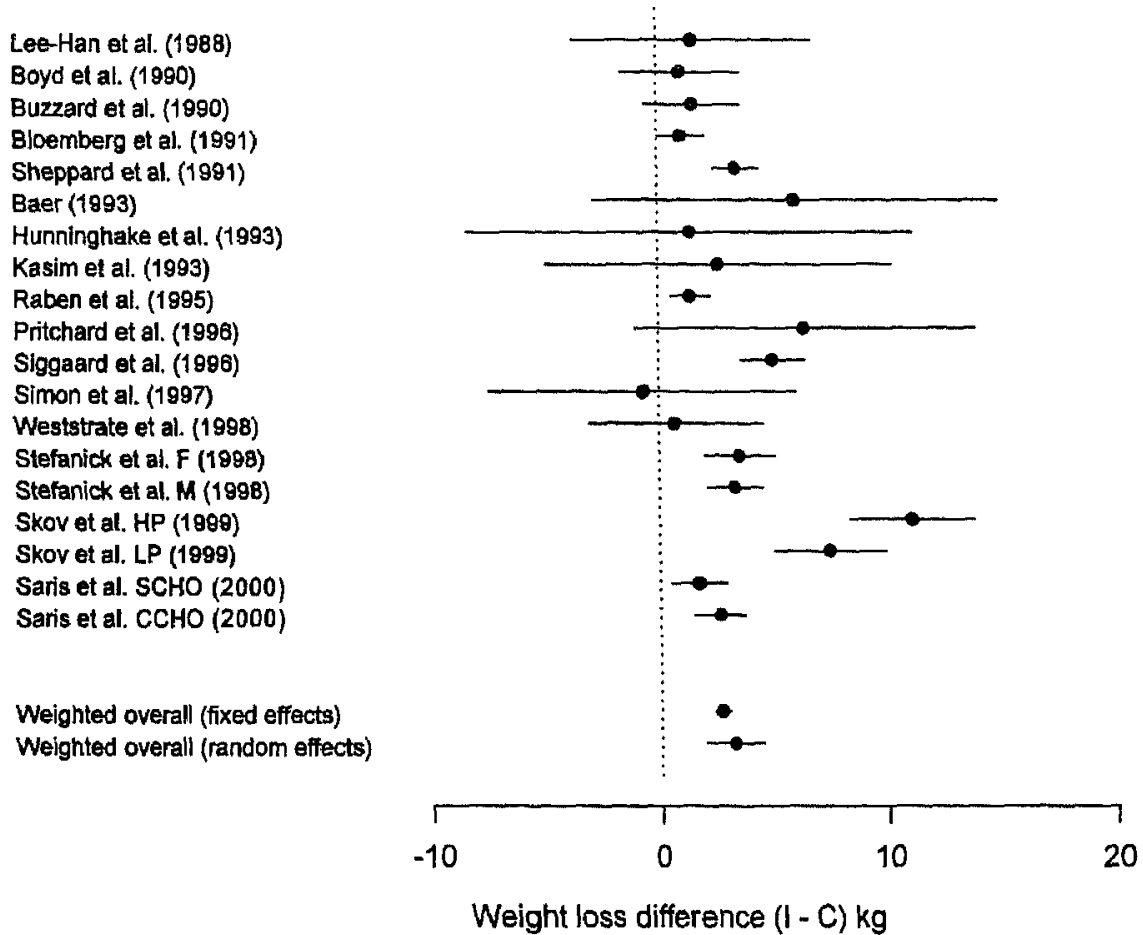

Figure 2 Differences in weight loss (change in intervention minus change in control; $\mathrm{kg}$ ) with $95 \%$ confidence intervals for 19 studies included in the meta-analysis. The weighted estimates and $95 \%$ confidence intervals from the fixed effects and random effects metaanalysis are also shown.

Program's Step I and Step II low-fat diets for reduction of cardiovascular risk factors, but had more liberal inclusion criteria than the present analysis and was therefore based on 37 dietary intervention studies. ${ }^{30}$ The weight loss in the intervention groups was $2.79 \mathrm{~kg}$ larger than in the control group, and there was a highly significant relation between reduction in dietary fat and weight loss, so that for every $1 \%$ decrease in energy from fat there was a $0.28 \mathrm{~kg}$ decrease in body weight ${ }^{30} \mathrm{In}$ contrast, our meta-analysis failed to detect an association between the reduction in dietary fat and weight loss, but this may be due to the reduced power because we included fewer studies.

Another important finding was that the weight loss was dependent on the pre-treatment body weight so that each $10 \mathrm{~kg}$ of initial pre-treatment mean body weight related to an additional $2.0-2.6 \mathrm{~kg}$ weight loss compared with control groups. Bray and Popkin in their weighted regression also found a large effect of initial weight and an added effect of being male. ${ }^{11}$ In individual studies it has previously been described that weight loss is positively correlated with pre-treatment body weight, such as in that of Schaefer et al $(r=0.68, P<0.001){ }^{31}$ Furthermore, Siggaard et al stratified subjects participating in a low fat ad libitum trial into normal weight $\left(\mathrm{BMI}<25 \mathrm{~kg} / \mathrm{m}^{2}\right)$ and overweight subjects $\left(B M I>25 \mathrm{~kg} / \mathrm{m}^{2}\right)$, and found that after 12 weeks the normal weight group had lost significantly less than the overweight group ( 2.5 vs $5.2 \mathrm{~kg}$ ). ${ }^{25}$ Raben $e t$ al also reported that initial body fat was an important determinant of weight loss achieved during a low-fat diet. ${ }^{21}$

No trials with groups of subjects with a BMI of more than $30 \mathrm{~kg} / \mathrm{m}^{2}$ fulfilled our inclusion criteria, so we cannot draw any conclusions on the potential of ad libitum low-fat diets to produce weight loss in obese subjects. The lack of studies in obese subjects fulfilling our inclusion criteria is somewhat surprising, and cannot explain the origins of the general view that low-fat diets are not effective in producing a clinically relevant weight loss in obese subjects. ${ }^{32}$ This assumption derives from trials conducted in overweight individuals, uncontrolled trials in obese subjects and two randomized studies comparing the ad libitum low-fat diet with an energy restricted diet. ${ }^{32}$ Shah et al found that the low-fat diet reduced body weight by $4.4 \mathrm{~kg}$ and the low-energy diet by $3.8 \mathrm{~kg}$ after 6 months. ${ }^{33}$ Jeffery et al found a 6 month weight loss of $4.6 \mathrm{~kg}$ on the low-fat diet and $3.7 \mathrm{~kg}$ on the low-energy diet, and similar regain in both groups after 12 months. ${ }^{34}$ These observations together with our analysis suggest that a mean weight loss of 4$5 \mathrm{~kg}$ can be obtained by obese subjects with a BMI around $30 \mathrm{~kg} / \mathrm{m}^{2}$. Although it may be a modest outcome in obese subjects whose weight exceeds the normal by $35-50 \mathrm{~kg}$, a $5 \%$ weight loss is considered to have an important beneficial effect on risk of morbidity. ${ }^{35}$

The reason for the larger weight loss with larger body fatness is not explained by the present study but a number of studies have suggested that genetically predisposed subjects may be more likely to gain weight on high-fat diets. ${ }^{36}$ Other studies have suggested this susceptibility to be linked to a lower ability to oxidize fat. ${ }^{37,38}$ If a higher susceptibility to weight gain on high-fat diets plays a role in the development of overweight and obesity, it is plausible that a 
reduction in dietary fat may also produce larger weight loss in susceptible individuals. The results of this meta-analysis may also have relevance for weight maintenance in obese subjects who have lost weight on a low-energy diet. A randomized intervention study demonstrated that $2 \mathrm{y}$ after a major weight loss a group of obese subjects who consumed an ad lib low-fat diet had regained, on average, $5.9 \mathrm{~kg}$ less than a group who cut down on all calories equally. ${ }^{39}$ Moreover, it has been shown that persons successful at long-term weight loss and maintenance are those who continue to consume a low-energy, low-fat diet. ${ }^{40}$

Apart from the pre-treatment body weight, duration and reduction of the dietary fat content a number of other factors may have influenced the magnitude of weight loss. Firstly, it is not possible to conduct longterm randomized controlled low-fat trials in a design blinded to the participants. In studies conducted for weight loss purposes the open design may tend to overestimate the intrinsic effect of the low-fat diet because the subjects in an effort to lose weight may voluntarily restrict their total energy intake or make other efforts to lose weight. However, in 11 of the 19 studies in this meta-analysis the goal of the study was not related to weight loss, and in some of the studies weight loss was even regarded as an undesirable effect $^{41}$ which was tolerated only during the first 11 weeks of the study. ${ }^{21}$ Consequently, it is not likely that voluntary energy restriction has confounded the outcome of the analysis severely. Secondly, in some of the studies the control groups did not receive counselling at similar intervals as the intervention groups, and it is possible that this may have contributed to the observed weight loss difference. However, in the studies by Weststrate et $a l$ and Saris et al the normal-fat control groups received the similar degree of counselling and all foods free of charge, and the outcome of these studies is within the confidence intervals of the meta-analysis. Thirdly, as with other lifestyle changes, adherence to the diet is crucial if an effect is to be observed. In the studies contributing to this meta-analysis, dietary compliance was assessed by dietary records, which allowed a calculation of energy and macronutrient intake during the trial. However, one should keep in mind that the information about the diet intake is self-reported by the participants and the validity is therefore questionable and the information may be idealized. If dietary fat intake is underreported the impact of low-fat diets on weight loss is underestimated and for a given dietary fat reduction the weight loss would be greater than estimated from the present analysis. Low-fat diets should not be blamed for lack of efficacy if the real reason for the lack of observed effect is the subjects' resumption of their former high-fat dietary habits. However, it remains to be seen whether the modest long-term effect of low-fat diets on body weight is due to non-compliance, or whether the subjects compensate when they become adapted to the low-fat diet.
In conclusion, this meta-analysis, based on 19 controlled, ad libitum, low-fat, 2-12 month intervention studies, shows that ad libitum, low-fat diets cause weight loss. The effect is more pronounced in subjects with a higher initial body weight. The meta-analysis revealed a $3.2 \mathrm{~kg}$ greater weight loss as a result of consuming a low-fat ad libitum diet. A decrease in the body weight of this magnitude in the general population could reduce the prevalence of obesity from $25 \%$ to $15 \% .{ }^{35}$ Even a few kilograms weight loss on a lowfat diet may, therefore, have an important public health impact, but increases in daily physical activity would also be desirable to strengthen the effect of preventive efforts.

\section{Acknowledgements}

Supported by grants from the Danish Medical Research Council and the Danish Food Technology and Nutrition Program (FØTEK), and NIH (DK42549 and DK48520).

\section{References}

1 Katan MB, Grundy SM, Willett WC. Beyond low-fat diets. New Engl J Med 1997; 337: 563-566.

2 Willett WC. Is dietary fat a major determinant of body fat? Am $J$ Clin Nutr 1998; 67: 556S-562S.

3 Schoeller DA. How accurate is self reported dietary intake? Nutr Rev 1990; 48: 373-379.

4 Prentice AM, Black AE, Coward WA, Davies HL, Goldberg GR, Murgatroyd PR, Ashford J, Sawyer M, Whitehead RG. High levels of energy expenditure in obese women. $\mathrm{Br}$ Med $J$ 1986; 292: 983-992.

5 Heitmann BE, Lissner L. Dietary underreporting by obese individuals - is it specific or non-specific? Br Med $J$ 1995; 311: 986-989.

6 Radimer KL, Harvey PWJ. Comparison of self-report of reduced fat and salt foods with sales and supply data. Eur $J$ Clin Nutr 1998; 52: 380-382.

7 Paeratakul S, Popkin BM, Keyou G, Adair LS, Stevens J. Changes in diet and physical activity affect the body mass index of Chinese adults. Int J Obes Relat Metab Disord 1998; 22: $424-431$

8 Lissner L, Levitsky DA, Strupp BJ, Kalkwarf HJ, Roe DA. Dietary fat and the regulation of energy intake in human subjects. Am J Clin Nutr 1987; 46: 886-892.

9 Stubbs RJ, Harbron CG, Murgatroyd PR, Prentice AM. Covert manipulation of dietary fat and energy density: effect on substrate flux and food intake in men eating ad libitum. $\mathrm{Am}$ $J$ Clin Nutr 1995; 62: 316-329.

10 Bennet C, Reed GW, Peters JC, Abumrad NN, Sun M, Hill JO. Short-term effects of dietary-fat ingestion on energy expenditure and nutrient balance. Am J Clin Nutr 1992; 55: 1071-1077.

11 Bray GA, Popkin BM. Dietary fat intake does affect obesity. Am J Clin Nutr 1998; 68: 1157-1173.

12 Astrup A, Toubro S, Raben A, Skov AR. The role of low fats diets and fat substitutes in body weight management: what have we learned from clinical studies? J Am Diet Assoc 1997; 97: $82 \mathrm{~S}-87 \mathrm{~S}$.

13 Lee-Han $H$, Cousins $M$, Beaton M, McGuire V, Kriukov V, Chipman $M$, Boyd N. Compliance in a randomized clinical trial of dietary fat reduction in patients with breast dysplasia. Am J Clin Nutr 1988; 48: 575-586.

14 Buzzard IM, Chlebowski RT, Jeffery RW, Boyar AP, Jeffery RW, Nixon DW, Blackburn GL, Jochimsen PR, Scanlon EF, Insull $\mathrm{W} J \mathrm{Jr}$ et al. Diet intervention methods to reduce fat intake: nutrient and food group composition of self-selected low-fat diets. J Am Diet Assoc 1990; 53: 42-50. 
15 Simon MS, Heilbrun LK, Boomer, Kresge C, Depper J, Kim $\mathrm{PN}$, Valeriote F, Martino $S$. A randomized trial of a low-fat dietary intervention in women at high risk for breast cancer. Nutr Cancer 1997; 27: 136-142.

16 Boyd NF, Cousins M, Beaton M, Kriukov V, Lackwood G, Tritchler $D$. Quantitative changes in dietary fat intake and serum cholesterol in women: results from a randomized, controlled trial. Am J Clin Nutr 1990; 52: 470-476.

17 Bloemberg BPM, Kromhout D, Goddijin E, Jansen A, Obermann de Boer GL. The impact to the guidelines for a healthy diet of the Netherlands Nutrition Council on total and high density lipoprotein cholesterol in hypercholesterolemic freeliving men. Am J Epidemiol 1991; 134: 39-48.

18 Baer JT. Improved plasma cholesterol levels in men after a nutrition education program at the worksite. $J$ Am Diet Assoc 1993; 93: 658-663.

19 Hunninghake DB, Stein EA, Dujovne CA, Harris WS, Feldman EB, Miller VT, Tobert JA, Laskarzewski PM, Quiter E, Held $\mathbf{J}$ et al. The efficacy of intensive dietary therapy alone or combined with lovastatin in outpatients with hypercholesterolenia. New Engl $J$ Med 1993; 328: 1213-1219.

20 Kasim SE, Martino S, Kim P, Khilnani S, Boomer A, Depper J, Reading BA, Heilbrun LK. Dietary and anthropometric determinants of plasma lipoproteins during a long-term low-fat diet in healthy women. Am J Clin Nutr 1993; 57: 146153.

21 Raben A, Due Jensen N, Marckmann P, Sandström B, Astrup A. Spontaneous weight loss during 11 weeks ad libitum intake of a low fat/high fiber diet in young, normal weight subjects. Int J Obes Relat Metab Disord 1995; 19: 916-922.

22 Stefanick ML, Mackey S, Sheehan M, Ellsworth N, Haskell WL, Wood PD. Effects of diet and exercise in men and postmenopausal women with low levels of HDL cholesterol and high levels of LDL cholesterol. New Engl J Med 1998; 339: $12-20$.

23 Sheppard L, Kristal AR, Kushi LH. Weight loss in women participating in a randomized trial of low-fat diets. Am J Clin Nutr 1991; 54: 821-828.

24 Pritchard JE, Nowson CA, Wark JD. Bone loss accompanying diet-induced or exercise-induced weight loss: a randomised controlled study. Int J Obes Relat Metab Disord 1996; 20: $513-520$.

25 Siggaard R, Raben A, Astrup A. Weight loss during 12 weeks ad libitum carbohydrate-rich diet in overweight and normal weight subjects at a Danish working site. Obes Res 1996; 4: $347-356$.

26 Westrate JA, van het Hof KH, van den Berg H, Velthuis-teWierik EJ, de Graaf C, Zimmermanns NJ, Westerterp KR, Westerterp-Plantenga MS, Verboeket-van de Venne WP. A comparison of the effect of free access to reduced fat products or their full fat equivalents on food intake, body weight, blood lipids and fat-soluble antioxidants levels and haemostasis variables. Eur I Clin Nutr 1998; 52: 389-395.

27 Skov AR, Toubro S, Rønn B, Holm L, Astrup A. Randomized trial on protein versus carbohydrate in ad libitum fat reduced diet for the treatment of obesity. Int $J$ Obes Relat Metab Disord 1999; 23: 528-536.

28 Saris WHM, Astrup A, Prentice AM, Zunft HJF, Formiguera $X$, Verboeket-van de Venne WPHG, Raben A, Poppitt SD, Seppelt B, Johnston S, Vasilaras TH, Keogh GF. Randomized controlled trial of changes in dietary carbohydrate/fat ratio and simple vs complex carbohydrates on body weight and blood lipids: the CARMEN study. Int J Obes Relat Metab Disord 2000; 24: 1310-1318.
29 Normand SL. Meta-analysis: formulating, evaluating, combining and reporting. Stat Med 1999; 18: $321-359$.

30 Yu-Poth S, Zhao G, Etherton T, Naglak M, Jonnalagadda, Kris-Etherton PM. Effects of the National Cholesterol Education Program's Step I and Step II dietary intervention programs on cardiovascular disease risk factors: a meta-analysis. Am J Clin Nutr 1999; 69: 632-646.

31 Schaefer EJ, Lichtenstein AH, Lamon-Fava S, McNamara JR, Shaefer MM, Rasmussen H, Ordovas JM. Body weight and low-density lipoprotein cholesterol changes after consumption of a low-fat ad libitum diet. JAMA 1995; 274: 1450-1455.

32 Clinical guidelines on the identification, evaluation, and treatment of overweight and obesity in adults-the evidence report. Obes Res 1998; 2: 51S-210S.

33 Shah M, McGovern P, French S, Baxter J. Comparison of a low-fat, ad libitum complex carbohydrate diet with a lowenergy diet in moderately obese women. Am J Clin Nutr 1994; 59: $980-984$.

34 Jeffery RW, Hellerstedt WL, French SA, Baxter JE, A randonized trial of counselling for fat restriction versus calorie restriction in the treatment of obesity. Int $J$ Obes Relat Metab Disord 1995; 19: 132-137.

35 WHO. Obesity: preventing and managing the global epidemic. Report of a WHO Consultation on Obesity, Geneva, 3-5 June 1997. WHO Publications: Geneva, 1997.

36 Heitmann BL, Lissner L, Sorensen TIA, Bengtsson C. Dietary fat intake and weight gain in women genetically predisposed for obesity. Am J Clin Nutr 1995; 61: 1213-1217.

37 Thomas CD, Peters JC, Reed GW, Abumrad NN, Sun M, Hill JO. Nutrient balance and energy expenditure during ad libitum feeding of high-fat and high-carbohydrate diets in humans. $A m$ $J$ Clin Nutr 1992; 55: 934-942.

38 Astrup A, Buemann B, Christensen NJ, Toubro S. Failure to increase lipid oxidation in response to increasing dietary fat content in formerly obese women. Am J Physiol 1994; 266: E592-E599.

39 Toubro S, Astrup A. Randomised comparison of diets for maintaining obese subjects weight after major weight loss: ad $l i b$, low fat, high carbohydrate diet $v s$ fixed energy intake. $\mathrm{Br}$ Med J 1997; 314: 29-34.

40 Shick SM, Wing RR, Klem ML, McGuire MT, Hill JO, Seagle $H$. Persons successful at long-term weight loss and maintenance continue to consume a low-energy, low-fat diet. $J \mathrm{Am}$ Diet Assoc 1998; 98: 408-413.

41 Sandström B, Marckmann P, Bindslev N. An eight-month controlled study of a low-fat high-fibre diet: effects on blood lipids and blood pressure in healthy young subjects. Eur J Clin Nutr 1992; 46: 95-109.

42 Astrup A, Ryan L, Grunwald GK, Storgaard M, Saris W, Melanson E, Hill JO. The role of dietary fat in body fatness: evidence from a preliminary meta-analysis of ad libitum low fat dietary intervention studies. Br J Nutr 2000; 83: S25-32. 